\title{
The Influence of Aman Abdurrahman On Pro-Isis Terrorist Networks In Indonesia After The Fall Of Isis In Raqqa And Mosul In 2017
}

\author{
Hany Widhyastri ${ }^{1}$, Muhammad Luthfi ${ }^{2}$, Muhammad Imdadun Rahmat ${ }^{3}$, Mulawarman \\ Hannase $^{4}$ \\ $\left\{{ }^{1}\right.$ hanywidhyastri@gmail.com, ${ }^{2}$ m.luthfiz009@gmail.com, ${ }^{3}$ imdadunrahmat@yahoo.com \\ ${ }^{4}$ mhannase@yahoo.com\} \\ ${ }^{1,2,3,4}$ School of Strategic and Global Studies, Universitas Indonesia, Indonesia
}

\begin{abstract}
ISIS became global attention with its purpose on bring back the caliphate era. But when Raqqa and Mosul as their 'Caliphate' was fallen, ISIS still a serious threat. Aman Abdurrahman, who since 2008 actively giving speeches about Tauhid also supporting and pledging allegiance to ISIS. Several terrorist attacks such as Sarinah bombing, Samarinda Church bombing, Kampung Melayu bombing, attack on North Sumatra Regional Police, and shooting police officers in Bima shows that he has succeeded in influencing pupils. Mako Brimob Riot and family of suicide bombers in May 2018 shows that Aman Abdurrahman's influence and ISIS propaganda was still spreading in Indonesia even after ISIS' lost. To understand this, we will be using social construction theory which become the basis of this qualitative research. In addition, in-depth interviews with former radical activists were conducted to see the internalization process. The urgency of this studies is to comprehend the basis thoughts about Jihad and analyze how his thoughts externalizes, and objectifies his pupils. Major findings of this studies, first, the shifting on Aman Abdurrahman's thought of takfiri berantai. Second, there are several factors that become a benchmark in forecasting pro-ISIS network in Indonesia.
\end{abstract}

Keywords: Radical Influence; Terrorism; pro-ISIS; JAD

\section{OVERVIEW}

Aman Abdurrahman has been active in giving radical-colored Da'wah since 2008, long before the establishment of ISIS. His thinking focuses on democracy which seen from the point of view of the teachings of Tauhid (the concept of one of Allah). He examines aspects of democracy which are considered as Syirik akbar (equating Allah with other beings) which actually not in accordance with the teachings of Tauhid (should be applied by every Muslim). In general, Aman Abdurrahman's thoughts are summarized in a collection of Da'wah recordings, his book entitled Seri Materi Tauhid, the Millah Ibrahim website and the testimonies of his students. His support for ISIS was based on the reason that ISIS was considered to be in accordance with the prophecies of Rasulullah SAW. Aman Abdurrahman then encouraged his students to pledge allegiance to ISIS. This baiat gave rise to the 
consequence that "when the door of Hijrah (moving towards faith) to the earth Sham is closed, then Jihad (earnest struggle) must be carried out in their respective places". As a result, his several pupils carried out various actions as a form of Jihad. This propaganda then led to the success of Aman Abdurrahman in internalizing his pupils. After the riot incidents at the Mako Brimob and family suicide bomb attacks in three churches and Mapolresta Surabaya in May 2018 it shows us that even though ISIS falls, support for the ISIS movement remains real, especially with the influence of Aman Abdurrahman's thinking in Indonesia. Regarding its support for ISIS, the construction of Aman Abdurrahman's thought was also influenced by a split about Thogut (every worship besides Allah) and Kufr in the body of ISIS scholars. This research would like to show that despite the split within ISIS, Aman Abdurrahman's basic thinking is the basis for strengthening his radical understanding. Therefore, it can be said that Aman Abdurrahman's thinking has a significant influence that triggers the birth of terrorism attacks.

This study uses a qualitative approach which is carried out by in-depth interview method and literature study. By exploring Aman Abdurrahman's train of thought through his books and lectures and analyzed the extent to which his thoughts were able to internalize, externalize and objectify pupils becomes an urgency for this research. Social Construction Theory will explain Aman Abdurrahman's interpretation of the Tauhid teachings, as well as it's contradictions with democracy. The findings in this study are a shift in Aman Abdurrahman's understanding of Takfiri (convicting someone based on Kafir) after he declared Baiat to ISIS. These changes turned out to stem from the split within ISIS. This split then influenced the characteristics of the pro-ISIS network in Indonesia. Another finding is that there are four factors that become a benchmark for forecasting pro-ISIS network movements in Indonesia in the future. These four factors include basic thinking, communication, networking, and media.

\section{PREVIOUS RESEARCH ABOUT AMAN ABDURRAHMAN AND ISIS}

Some previous research has become a reference for this study, including: 1) Aman Abdurrahman's control over JAD known as a terror group that has dominated the last few years in Indonesia and how JAD will continue its dominance in 2018 by targeting the police. (Habulan, Taufiqurrohman, Haziq, et al, 2018); 2) Aman Abdurrahman played an important role in disseminating propaganda and assisting ISIS recruitment even when he was in prison (Moir, 2017); 3) propaganda and virtual ISIS Caliphates that are still a threat after the fall of Raqqa and Mosul (Huzaifah \& Mahzam, 2018); 4) the defeat of ISIS gave birth to a new strategy, namely by forming and securing new territories through its support base in various regions of the world and utilizing virtual tribe as a new method of achieving ISIS's goals (Dhanaraj, 2018); 5) basically on the one hand ISIS succeeded in inspiring its supporters to continue to carry out attacks, even though on the other hand Syria and Iraq were not successfully defended by ISIS (Gunaratna, 2018), and 6) The National Counter Terrorism Agency (BNPT) have never analyzed Aman Abdurrahman's study content (IPAC, 2015).

\section{SOCIAL CONSTRUCTION THEORY}

This research uses social construction theory initiated by Peter L. Berger and Thomas Luckman. Through this theory, Berger and Luckman have introduced that between objective social facts and the subjective reality of society have essential relationships. (Dreher, 2016). 
So that it can be said that in the analysis of social construction there is a dialectic between subjective and objective reality. This concept also provides two main frameworks that 1) actors shape society while directing the attitude of society based on the subjective reality built by these actors; and 2) such actors are in fact also shaped by society and their objective reality. Furthermore, there are three processes that occur in social construction theory, including internalization, objectification, and externalization. Internalization is a social process that occurs through the subjective awareness of an individual obtained through socialization. Externalization is the interaction process that forms human products. Then when the externalization meets with knowledge, it will produce objective reality. The externalization process then becomes the forerunner to objectification. These three processes carry the idea that in social construction, society is a human product, and human is a social / community product (Dreher, 2016).

\subsection{Aman Abdurrahman}

Oman Rochman Bin Ade Sudarma a.k.a Abu Sulaiman a.k.a Aman Abdurrahman, was born on January 5, 1972 in Sumedang, West Java (Kejaksaan Negeri, 2018). Abdurrahman Aman's name is always referred with the title "Ustadz" (lecturer or speaker in Islam) by both students and former students. As a graduate with cumlaude predicate from LIPIA Jakarta (Islamic and Arabic Science Institute) Aman was known to have a deep religious understanding, maybe even more profound than a Ustadz Abu Bakr Baashir (Widodo, 2018). Before leaving the prison, Aman Abdurrahman used to deliver lectures, Da'wah and other studies when he was still the imam of the Jami'Al-Sofwa mosque in the Lenteng Agung, South Jakarta. However, when the religious studies presented were considered extreme, Aman Abdurrahman was fired. (Widodo, 2018). Aman Abdurrahman always put forward the discussion about Tauhid in each of his lectures. A calm and relaxed voice actually contradicts the content of Da'wah delivered. According to one of Aman Abdurrahman's former students, he used the justification method in his approach when delivering his Da'wah (Al-Indunisy, n.d.). He openly criticized the democratic system in Indonesia as part of the syirik akbar. The religious interpretation by Aman Abdurrahman eventually became a reference for extremist groups in Indonesia. He was known as the person who brought together various pro-ISIS groups in Indonesia into one forum.

\subsection{Relation Between Social Construction Theory and Aman Abdurrahman Thoughts}

The theory of social construction is used in this study to describe the thoughts of religious teachings by Aman Abdurrahman. He basically managed to internalize, externalize and objectify the students and pro-ISIS supporters in Indonesia. The internalization process is reflected through the awareness of students and their supporters about democracy which is contrary to the teachings of Tauhid from Allah. This awareness is certainly born from the process of following Aman Abdurrahman's religious studies. This internalization can also be seen as a form of individuals who identify themselves in the midst of social institutions where individuals become members. Which in this case the individual is a follower of Aman Abdurrahman while the social institution can be a Aman Abdurrahman himself. Then the externalization process in general is illustrated through self-adjustment and interaction between Aman Abdurrahman's followers who join themselves into the JAD as a forum to support the struggle of the ISIS Islamic Caliphate in Syria and Iraq. Finally, objectification is 
reflected through the results of social interaction between pilgrims and Aman Abdurrahman or JAD which gave rise to radical anti-Democracy thinking as well as amaliyah Jihad supporting ISIS's movement, which results are seen as objective reality.

This is in line with what was explained by Rietzer (2010) in the social matrix analysis that the perceptions and beliefs built into social construction theory are micro-subjective. This means that in this case, religious views or teachings are subjective realities that were built by individuals. Then the internalization process is called an important key in integrating with the existing social system. This internalization occurs when the values and norms are transferred to the individual and the individual in question is able to absorb these values and norms into his subconscious, then in that phase there is internalization (Parsons in Rietzer, 2010). Therefore, when the anti-democratic values built by Aman Abdurrahman and the pledging allegiance to ISIS were then distributed to the students and their supporters by various methods, the internalization process had taken place. Furthermore, the externalization and objectification processes above can also be explained through Rietzer's concept that the actions and interactions that occur are micro-objective (Rietzer, 2010). In terms of microobjective, radical views and terrorism acts are seen as truth or objective reality. So that overall the micro-subjective and micro-objective sides also reinforce Berger and Luckman's statement above that every form of social phenomenon will have a subjective and objective side (Rietzer, 2010).

Basically, the construction of thought that was built by Aman Abdurrahman did not necessarily appears without an influence from the surrounding environment. Aman Abdurrahman's radical thinking long before the advent of ISIS itself might be influenced by educational and professional institutions with a religious background. The depth knowledge of religion and Arabic language skills that Aman Abdurrahman possessed were later also influenced by media institutions. The presence of mass media that promotes the spread of the news of the establishment of the Islamic Caliphate and a call to Hijrah and Jihad for Muslims throughout the world then further encourages the construction of Aman Abdurrahman's thoughts which were originally of extreme basis and then become increasingly more radical. The concept of social construction also occurred when the separation of the ulama camp inside ISIS ultimately influenced the construction of Aman Abdurrahman's thought, especially regarding Takfir.

\subsection{Aman Abdurrahman Thought's before ISIS}

Basically, the process of internalization carried out by Aman Abdurrahman begins with the construction of his perspective towards religious teachings. Therefore, to find out the results of the internalization, an in-depth understanding of the background of the thoughts developed by Aman Abdurrahman was needed. Aman Abdurrahman's actions was not well known to the public before this year, though he had delivered many Tauhid studies to his followers in various regions in Indonesia such as Jakarta, Surabaya, Lamongan, Balikpapan, and Samarinda since 2008 (Kejaksaan Negeri, 2018). His understanding, again, criticized The Democracy system. Through this perspective, Aman Abdurrahman suggested that everyone who claims to be a Muslim should be obliged to escape the democratic system. Moving on from his thinking, Aman Abdurrahman was considered as a reference for the study of Tauhid (Kejaksaan Negeri, 2018). Those teaching caused his pupils to hold the view that 1) current government system in Indonesia is a syirik akbar; and 2) anyone who is willing to implement man-made law (in this case the state apparatus) is obliged to be fought. 
Moving on to 2009, Aman Abdurrahman was sentenced to nine years in prison for his involvement in a military training event in Jalin Jantho, Aceh. Aman Abdurrahman later served a prison sentence at the Nusa Kambangan Correctional Institution (LP), Cilacap, Central Java. Inside this prison, Aman Abdurrahman established a relationship with fellow terrorists. In addition, many of his followers outside the prison went to visit Aman Abdurrahman. That opportunity was used by Aman Abdurrahman to deliver a lecture and study about Tauhid based on his thoughts (Kejaksaan Negeri, 2018). Through this lecture and book written by Aman Abdurrahman, this process of internalization is being pursued so the radical Tauhid teachings can be understood and accepted as truth by the students and their supporters.

Based on the book of the Tauhid Material Book Series, Aman Abdurrahman tried to review the disbelief of democracy in more details. He explained that democracy has several teachings (Aman Abdurrahman, 2010), namely: 1) the legal source of democracy is from the people; 2) the law used is not Allah's law but man-made law; 3) provide freedom of belief and opinion; 4) truth based on majority vote; 5) Allah is diverse; and 6) equality of rights. Democracy is known as coming from the people, by the people, for the people (sovereignty and power at the hand of man), whereas the source of power and law should be in Allah's hand. Aman Abdurrahman emphasized this concept to prove that the use of man-made law in the democratic system is a syirik akbar. Aman Abdurrahman also stated that even though there are one or several laws in a democratic system similar to the teachings of Islam, they are still not the law of Allah. (Aman Abdurrahman, 2010). Through Aman Abdurrahman's book (2010), democracy is considered to protect, recognize, guarantee religious freedom. The value of freedom is considered to open roads that lead to kufr and apostasy. Islamic law is considered to be contrary to the value of freedom. In addition, the habit of forming decisions based on majority vote is considered directing the most votes as the only truth (Aman Abdurrahman, 2010). This last point actually shows that he does not want pupils to believe in democracy as a truth. Therefore he tried to provide understanding of religious teachings to contradict the value of democracy. This effort shows that the teachings built by him are microsubjective as stated by Rietzer (2010) in his social analysis matrix.

Aman Abdurrahman's efforts to oppose democracy by building a certain understanding through the values of Tauhid, and explanation of thaugut and kufr. Tauhid teaches Muslims that Allah is the only owner of power over all laws. Aman pointed out that law enforcers in a democratic system are the people themselves, which in fact quite big in number (Aman Abdurrahman, 2010). Since there are a lot of people, this opened up the chance for different figures of Allah. Aman feared this would happen and it would make Tauhid slowly forgotten. Regarding Thaugut, Aman Abdurrahman quotes Qur'an Verse An Nahl: 36 that the first obligation of Muslims is to have faith in Allah and stay away from Thaugut. Aman Abdurrahman argue that although a Muslim performs prayers, alms, Shaum, Hajj (religious pilgrimage), and others, but not Kufr towards Thaugut, then that person is not a true Muslim and his deeds will not be accepted by Allah. Moving on from that, he described the procedure of Kufr towards Thaugut as taught by Shaykhul Islam Muhammad Ibn Abdil Wahhab Rahimahullah, among others: 1) Know that faith to other than Allah is unacceptable; 2) abandoning Syirik activities; 3) hate Syirik activities; 4) claim those who perform Syirik Akbar / Thaugut as a sinner; and 5) hostile to the perpetrators of Syirik Akbar / Thaugut (Aman Abdurrahman, 2010).

Aman Abdurrahman's perception of Thaugut is a devil, a despotic ruler, one who decides in addition to those revealed by Allah, those who know the unseen except Allah, and those who are worship other than Allah. Then Aman Abdurrahman also explained about the 
Ansharut Thaugut or Thaugut forces in Seri Materi Tauhid book. Anshar Thaugut by word and writing consisting of government clerics who labeled anti-Thaugut fighters as khawarij and print and electronic media as those who spread understanding and helped strengthen the Thaugut system. On the other hand, Ansar Thaugut with weapons or physical strength between members of the police as security officers of the Thaugut government, the army as the protector of the infidel state, and intelligence as a collection of people who spy on the Muslims (Aman Abdurrahman, 2010). Aman Abdurrahman himself in 2010 has given his students about the details of civil servants's status working in the Thaugut government.

According to his book (2010) there are three differences including Kufr work, work that is of a major sin, and work that is not classified into both categories. First, Aman said that Kufr activities consist of five points, among others: 1) when the member of House of Representative draft bills and creating legal products; 2) all sort of works that decides the law (other than the law of Allah) such as prosecutor or judge; 3 ) positions that defend or protect the Thaugut system such as the police, army and intelligence work; 4) workers who are loyal to Thaugut law such as employees of the Ministry of Law and Human Rights; and 5) people who swear to be loyal to Thaugut, in this case civil servants who become Kafir because of their oaths not their job (example 1 untill 4 shows people who become Kafir because of the job, regardless with oath or not). Second, works that are considered Haram such as custom officials and banks, because the field of customs and banks (banks are considered as Riba) are considered illegitimate due to injustice. If those who work there swore an oath, the two types of work are deemed as unlawful work (because of their injustice) and Kafir (work because of their oath). Third, jobs which count as Mubah are jobs that are not forbidden because of illegitimate and not Kafir because of oath. For example, work in the social service, health department, agricultural service, or marine service. Aman Abdurrahman said that the field of work referred to by the ulama contained Makruh law if the employees afraid to show their beliefs. Regarding jobs, Aman elaborated that he himself didn't know whether those civil servants really swore an oath, since the only who knew are themselves and Allah, so in other words cannot be called as Kafir (Abdurrahman, 2010).

Referring to his criticism to the democratic system, Aman Abdurrahman subjectively tried to build awareness to his students and their supporters about the heresy of democratic system. Furthermore, the elaboration of the teachings of Tauhid, Thaugut, Ansar Thaugut, and Kufr showed that Aman seeks to build an objective reality through these values and norms so that his students and supporters are able to understand and accept it as truth. This is an example, which explained that a social phenomenon can contain subjective and objective reality at the same time.

\subsection{Aman Abdurrahman Thought's After ISIS}

The construction of thoughts that Aman Abdurrahman possesses is slowly changing or reconstructing because of the presence of ISIS which fosters enthusiasm or Ghirah among Muslims around the world to support the establishment of the Caliphate. After ISIS declared the Caliphate Islamiyah in Syria at 2014, Aman took the position to call on some of his students and convey about the establishment of the Islamic Caliphate on the land of Sham which according to Aman Abdurrahman was in accordance with the prophecy of the Prophet Muhammad SAW. Aman Abdurrahman then taught his students that a Muslim must support and declare the allegiance to the Islamic Caliphate led by Abu Bakr Al-Baghdadi. In addition, he also said that supporters of the ISIS caliphate need to form a group so that worshipers in Indonesia could unite with the aim of equating Manhaj, namely Manhaj Daulah Islamiyah. 
Through this forum, it is also expected to help people who want to take pilgrimage to Sham (Kejaksaan Negeri, 2018).

Aman Abdurrahman then invited his followers to pledge allegiance in Arabic to ISIS with the contents of the allegiance: "We pledge allegiance to Amir al-Mu'minin Syeh Abu Bakr AlBaghdadi to listen and obey, both in voluntary and forced circumstances, both in easy and difficult conditions and we will not revoke this case unless I see the real disbelief that we have evidence of Allah SWT "(Kejaksaan Negeri, 2018). Referring to the Bai'at, everyone has to obey all the calls of Abu Bakr Al-Baghdadi including, if he is able to, then he must emigrate to the land of Sham. For those who are unable to emigrate, the the choice is to do Jihad in his own country.

The Amaliyah Jihad recommended by Aman Abdurrahman is basically inseparable from politics in the body of ISIS. According to the findings in the field, former Aman student Abdurrahman (Anonim, 2018 \& Widodo, 2018) stated that there was a split of the Ulama in the body of ISIS. The Caliphate which is echoed by ISIS is known to have an institution consisting of scholars who have recognized their expertise in the knowledge of Islam. The Ulaam institution was named Lajna Mufawwadhah (LM), one of whose main tasks was to support the Caliphate. These Ulamas who were scattered in various provinces, departments, committees, and offices were then divided into two camps, namely the Ahmad al-Hazimi and Turkey Al bin Ali. Between Hazimi and Turkey Al bin Ali or non-Hazimi are known to share a Takfiri view, but Hazimi is called the ghuluw-takfiri because the Hazimi camp is able to label the infidels to the third level or takfir berantai. This simple example of takfir berantai is when there are three stakeholders. If there is someone who is considered a Syirik Akbar perpetrator, then the second person who does not treat the first person is at the second level. Furthermore, a third person who does not share in the deeds of the second person who does not accuse the first person is called in the third level. For the Ulama of the Ahmad al-Hazimi group, they apply Kafir Uzur Kebodohan towards the first person, second person, and even third person (Anonim, 2018 \& Widodo, 2018). However, the Turkish group of Al bin Ali imposed Kafir Uzur Kebodohan on the second person and third person. Whereas the first person or the Syirik Akbar perpetrator applies unbelief without being foolish. Because it is considered knowing their actions are contrary to the teachings of Islam.

The difference of views followed by the split in the body of ISIS is not much known by its supporters. This division does not necessarily influence every supporters of ISIS Caliphate in areas other than Syria and Iraq, but for some of them who truly understand the history and follow the development of ISIS, this difference in views are significant. One of them was Aman Abdurrahman whose thoughts were influenced by the pros and cons of Hazimi. Construction of Aman Abdurrahman's thinking even before the ISIS declaration was classified as a radical understanding even though it had not reached what it is today. At that time, Ansar Thaugut activities was jobs that were directly related to the legal system, law enforcement, to legal protection. Additionally, Aman Abdurrahman still finishing other jobs he deemed as Kafir (because of an oath of allegiance to the state) and Haram (because the type of work contains elements of tyranny). He also agreed and marked civil servants in the non-legal field as Makruh and who continued to show his belief in Islam even though he had sworn allegiance to the state. Finally, despite his understanding of how Kafir the democratic system in Indonesia is, Aman Abdurrahman himself did not dare to makred civil servants as Kafir individually because basically he realized that only Allah knew whether the civil servants really swore or not.

It was seen that non-Hazimi was in accordance with Aman Abdurrahman's thoughts before he pledges alliance to ISIS. Currently, Aman Abdurrahman tend to lean on Hazimi. This is in 
line with what was said by a someone that Aman Abdurrahman himself had two thoughts about Takfir which were divided into two periods: before and after the appearance of ISIS. The Takfir problem specifically discusses the status of civil servants labeled as Kafir or not. Generally, it is about Kafir without exception and with exception (Anonymous, 2018). He was later known to provide a study of Kafir without excdption or in other words leads to Hazimi. This thought later became a basic meaning for JAD members until this group created brutal attacks and was labeled the most dangerous terrorist group of late.

At this stage, an important process had taken place in Aman's thought process, and that is when he no longer elaborated on the matter of Takfiri as he had previously done in Seri Materi Tauhid. Previously, Aman still had deep consideration of the Kufur status from civil servants. After the influence of ISIS emerged and spread through global media, he shifted his understanding that he deemed every civil servant, without exception, are Kafir and must be fought. According to one of his former students, the influence of ISIS has made Aman Abdurrahman himself take part in total disbelief to every government employee. This is also based on the fact that around 2017 there was an insistence from the supporters of the Islamic Caliphate in Syria so that Aman Abdurrahman would no longer specify the definition of Kafir (Widodo, 2018). This change of thought by Aman Abdurrahman shows that as the creator of objective reality in the eyes of students and their supporters, Aman Abdurrahman actually also experienced an internalization process or subjective reality when he absorbed the values and norms carried by ISIS into the construction of the thoughts he had built previously. Therefore, it needs to be illustrated that social phenomena always contain two sides namely subjective and objective.

\subsection{The Terrorism Incidents}

Based on Ghirah (enthusiasm) and Baiat on ISIS as previously explained, JAD was formed as a forum to unite Jamaah (members) with manhaj Daulah Islamiyah (Islamic State rules). Someone named Marwan alias Ari Budiman aka Abu Musa was also appointed as the Amir (leader) of the Jamaah whose job was to strengthen all supporters of the Caliphate Islamiyah spread throughout Indonesia. Abu Musa also served to accommodate his congregation in various different groups. Aman Abdurrahman himself played a role in moving the JAD by spreading the Tauhid Da'wah (Kejaksaan Negeri, 2018). This is done with the aim that the members of JAD can carry out Hijrah and Jihad to condemned and fight the government, along with its apparatus.

A year later around November 2015, JAD then organized a national Dauroh Da'i with a cover story on herbal medicine processing. Aman Abdurrahman who was in Nusa Kambangan Prison via video call gave a lecture or study to Dauroh participants about several things including Tauhid and Jihad, the law of sending children to school in public schools, fight Syiah, orders to immediately start Jihad so as not to wait for 2018. In this context, Aman wanted to unite all members of the JAD and try to move his people to Hijrah to Syria. As a result, after Dauroh is implemented, every followers of Aman in Indonesia plan to prepare for Amaliyah Jihad to fight the Kafir groups. (Kejaksaan Negeri, 2018).

One of the former terrorism convicts who once declared ISIS in Solo said that the formation of JAD in Indonesia was basically non-procedural because of the lack of clear rules and no proper training carried out in the JI group (Anonim, 2018). However, the existence of JAD apparently still attracts the supporters for the ISIS Caliphate in Indonesia. As a forum to support ISIS's struggle in Syria, the formation of the Ansar Daulah congregation (supporters of the Daulah) and transformed into a special organization called JAD actually describes the 
occurrence of an externalization process based on social construction theory. This externalization process was also reflected when students and Aman Abdurrahman supporters interacted and began to adapt themselves to the values and norms that Aman Abdurrahman built in the previous internalization phase.

Furthermore, when the externalization process meets with knowledge, it will generate interactions and actions based on the objective reality obtained by students and Aman Abdurrahman's supporters and accepted as the truth. The process of externalization and objectification was realized in a series of acts of terrorism that were masterminded by Aman Abdurrahman's teachings as a reference for Tauhid. Students and Aman Abdurrahman supporters who experienced the institutionalization process became JAD groups then communicated with each other. This is because the condition of Aman Abdurrahman is undergoing imprisonment so that the spread of thought, study material, and his support for ISIS also needs support from his students so his objectives can be achieved.

That shared goal is then manifested in the JADs series of actions in the midst of society. Most of the acts of terrorism that took place in Indonesia occurred because they were masterminded by the results of the thoughts and studies of the Aman Tauhid and the influence of the views of ISIS. The series of actions in the period of 2016 to 2017 also took place a year after the national reconciliation of JAD which echoed that the members of JAD did not wait for 2018 for Jihad (Kejaksaan Negeri, 2018). Aman Abdurrahman's capability to control JAD with his thinking made JAD known as the dominant terror group today (Habulan, Taufiqqurohman, Haziq, et al, 2018).

The first action that was proven in court that was the result of the influence of Aman Abdurrahman's thought was the Sarinah Thamrin Bomb. The incident began with Saiful Munthohir alias Abu Gar as Amir of the JAD in Ambon who visited Nusa Kambangan Prison to meet Aman Abdurrahman. A copy of the demand outlines that Aman Abdurrahman and Iwan Darmawan Muntho alias Rois, the closest people conveyed orders from the leadership of the Islamic Caliphate in Syria to carry out Alamiyah Jihad as had happened in Paris, France. The Amaliyah target of Jihad is a French citizen or a Russian citizen. The amaliyah Jihad planning led to acts of terrorism which on January 14, 2016 ago. Another series of acts of terrorism occurred after the perpetrators followed the study of Aman Abdurrahman Tauhid and pledged allegiance to ISIS, which included the action of the HKBP Oikumene Samarinda Church Bomb on 13 November 2016 conducted by JAD in East Kalimantan and the action of Kampung Melayu Terminal Bomb on 24 May 2017 carried out by JAD in Bandung area (Kejaksaan Negeri, 2018). Based on the trial process, it was found the fact that all of the series of actions took place because the Da'wah and studies delivered by Aman Abdurrahman had triggered students and supporters to carry out amaliyah Jihad as they could.

Not only through recording lectures or through his book, the spread of Aman Abdurrahman's thoughts is also carried out through technology and the media. This happened when one of Aman Abdurrahman's students created a Millah Ibrahim website to contain Aman Abdurrahman's study of Jihad, denying Thaugut, to the issue of democratic Syirik. The site was intentionally made to make it easier for everyone to access the lecture or study of the Aman Tauhid Aman Abdurrahman. As a result, one of his followers named Syawaluddin Pakpahan alias Abu Fadilah alias Rahmat Parlindungan bin Herman Pakpahan had a radical understanding, among others: 1) Jihad is a fardu a'in (an obligatory activity in Islam) for Muslims everywhere, 2) the law in Indonesia is a misguided law because it is made by humans; 3) do not want to be involved in general elections, 4) do not want to pay respect to the Red and White flag because it is Kufr. This thought led Syawaluddin Pakpahan and his colleagues to the North Sumatra Regional Police on June 25, 2017 (Kejaksaan Negeri, 2018). 
Indirect provocation of the teachings of radical colored Tauhid carried out by Aman Abdurrahman through Seri Materi Tauhid and the Millah Ibrahim website has also led to the understanding of a follower trying to break away from the democratic system of government in various ways (Kejaksaan Negeri, 2018), namely: 1) no will be involved in general elections at any level; 2) will not want to work as a civil servant; 3) will not recognize the current law in Indonesia; 4) hate the Indonesian democratic system of government; and 5) striving to uphold Islamic Shari'a in Indonesia by striving to fight Thaugut and Ansar Thaugut. This radical thinking then triggered Muhammad Ikbal Tanjung aka Ikbal alias Usamah to shoot police officers in Bima City, West Nusa Tenggara. The action was known to be intentionally carried out to create a widespread atmosphere of terror in the midst of society. Dhanaraj's (2015) research that Aman Abdurrahman's figure had a lot of influence on terror groups in Indonesia with their pro-ISIS ideology. Moir (2017) also mentioned that propaganda propagation and assisting pro-ISIS recruitment when he was in prison reflects how important the role of Aman Abdurrahman. So referring to the influence of ISIS, Aman Abdurrahman's thinking reflects the change in his Takfiri view from non-Hazimi towards Hazimi.

Aman Abdurrahman's thoughts either through lectures or studies he delivered directly, through the recording of Friday prayer speeches, the book Tauhid Material Series, and through the Millah Ibrahim website have made Tauhid studies accessible not only by students and followers, but also by anyone who gain access to recordings of lectures, books and sites. Aman Abdurrahman's students and supporters were finally internalized, externalized, and objectified because eventually they shared the understanding that the democratic governance system in Indonesia was a Syirik akbar. They also finally saw that the government apparatus (TNI, Polri, DPR, MPR, and others) were considered infidels and should have been fought because they applied man-made laws. Based on information from some of his former students, Aman Abdurrahman had transformed themselves into easy-to-label Kufr people and easily gave "hell sentences" to people who were not in agreement with Aman Abdurrahman regarding the issue of ijtihad (an effort to seek knowledge seriously). If there is a student who is different in Ijtihad, Aman Abdurrahman's students will be hostile towards that person (AlIndunisy, n.p.). This process is a concrete manifestation of the results of externalization and objectification carried out by Aman Abdurrahman on his students. Social construction by him also encourages the growth of the pro-ISIS network in Indonesia, especially those who are oriented towards the Hazimi Ulama.

\subsection{Projection of Pro-ISIS Network in Indonesia}

Since July 2017, the strength of ISIS's Islamic Caliphate has been known to reduced along with the loss of ISIS's control of Mosul in Iraq as the fort of ISIS. Then throughout 2017 until November 2017, ISIS was also increasingly pressured by its defeat in maintaining the center of the Islamic Caliphate in Raqqa, Syria (Huzaifah \& Mahzam, 2018; Dhanaraj, 2018). Referring to research Huzaifah and Mahzam (2018) states that there are four assets that will continue to support the ISIS jihad movement and will still be able to pose serious threats in the future, namely 1) the ideology and vision of the caliphate, 2) its territorial territory. 3) troops and supporters, and 4) internet and social media. Considering that from the very beginning ISIS did invite its supporters around the world to join in fighting together to support the Islamic Caliphate both by hijrah to the land of Sham and jihad in their respective countries, then basically if the four elements above are still owned and accessible to ISIS, then the struggle of ISIS in the future is likely to continue with the model of jihadist movements globally and sporadically. Especially with the help of technology, efforts to recruit and 
radicalize followers and plan plots of terror attacks will certainly be much easier to do. In addition, as Gunaratna (2018) researches, the territorial defeat of ISIS is an inspiration for supporters to continue to carry out jihad. Therefore, although ISIS seems difficult to do propaganda because it has lost two important territories such as Mosul and Raqqa, the movement of ISIS will continue as long as there are still cells supporting ISIS spread throughout the world, one of them is in Indonesia.

Referring to the split within ISIS in Raqqa as previously explained, the pro-ISIS network in Indonesia is automatically divided in terms of understanding related to takfiri. Some proISIS in Indonesia are known to be very radical and some view that takfiri needs more in-depth consideration and assessment. The fall of Mosul and Raqqa at the end of 2017 were viewed as the beginning of the decline of the ISIS Islamic Caliphate. Then in mid-2018 Indonesia was again shocked by a series of terrorism incidents that were masterminded by JAD who openly claimed to be oriented towards the ISIS flag. The first incidents was a riot at the Mako Brimob. Riots between police officers and prisoners of terrorism cases (with majority are members of JAD) that occur resulted on the prisoners take control of the armory. In this riot, Aman Abdurrahman was also asked to be a moderator for the majority of prisoners who were members of JAD.

The second bloody event was a series of family suicide bombings that took place in Surabaya, East Java. The suicide bombings which even included woman and children was aimed at churches that were holding Sunday services and Mapolrestabes Surabaya. This family's suicide bombing became a spotlight both at the local, national, regional and international levels because the act of blowing themselves up for jihad this time was carried out by whole family which consisted of father, mother and children. While the bombers in three churches, Gereja Pantekosta Pusat (GPPS) Jemaat Sawahan, Gereja Kristen Indonesia (GKI) Diponegoro, and Gereja Katolik Santa Maria Tak Bercela, Dita Oeprianto's family is known to be part of the JAD group in East Java. In addition the recitation network was followed by the family of Dita Oeprianto in the form of family recitation was also followed by Anton Ferdiantono's family (a bomb maker who exploded at Wonocolo Flats in Sidoarjo, East Java) and the family of Ilham Fauzan who was one of the perpetrators caught (Emil, 2018) Even though the family's suicide bombing was linked to JAD, Aman Abdurrahman was rejecting their actions as part of jihad. After those deadly attacks, there were approximately 200 suspected JAD terrorists in several regions in Indonesia who were arrested by the Indonesia's Special Anti-Terrorism Group (DENSUS 88 AT) (Amindoni, 2018). The bloody attacks in Surabaya as written in Habulan's article, Taufiqurrohman, Haziq, et al (2018) proposes how JAD will continue its terrorist domination in 2018 with police officers as their main target.

According to one former ISIS activist, the projection of the pro-ISIS network can be measured by four things. The first measure is basic thinking. The second benchmark is communication. The third measure is network. The fourth benchmark is media (Anonymous, 2018). So, at first there is basic thinking which then forms communication. Communication that occurs then growth into network. Furthermore, the network will growth into a media. As long as there is still media, the influence of ISIS towards people will always be there. The anonymous resource also explained that if there is only a thought but there is no communication, it can paralyze the development of that influence. This statement is in line with Dhanaraj's (2018) research on the evolution of ISIS after its defeat which suggested that ISIS used social media to spread its propaganda while give a sense of belonging among its support groups. It is the sense of belonging and community in social media that keeps ISIS 
propaganda still developing even though the ISIS Islamic Caliphate is considered to have fallen.

In essence, basic thinking as the first benchmark is owned by any group, for example $\mathrm{Al}$ Qaeda, JI (Jamaah Islamiyah), and ISIS, all of this groups have a basic common ground. How many basic rules cannot be calculated in percentage terms, but the basic rules must exist. For example, the idea of JI was represented by PUPJI (General Guidelines for the Struggle of Al Jamaah Al Islamiyah), ISIS was also represented by manhaj from Al-Baghdadi. This manhaj if compared to PUPJI basically will have the same basic rules. An examples of the most extreme basic thinking are based of the Qur'an. Even though there are differences in interpretation, the basic thinking actually originates from things that are broadly the same. This is what is referred to as a simple example of the point of meeting basic thinking from radical groups to point to radical-terrorism (Anonim, 2018). Therefore, the pro-ISIS terrorist network in Indonesia will continue to exist because the basic thinking still exists. Moreover, accompanied by technological advances in the modern world that accelerate the emergence of terrorist cells (Anonim, 2018). ISIS itself is known to be working on its strategy to form virtual caliphate or virtual tribe as a step to spread its religious thought propaganda (Huzaifah \& Mahzam, 2018 \& Dhanaraj, 2018). This shows that the more advanced and sophisticated technological tools will be increasingly used by terrorists and terrorist groups to launch their movements. The more sophisticated technology, 'sleeping' cells can wake up because the presence of technological sophistication is able to form communication, networking and media.

\section{CONCLUSION}

The pro-ISIS network in Indonesia is projected to remain in the future, although it cannot be known what form it will be. The results of this study are that the possibilities that can occur towards pro-ISIS networks in Indonesia include 1) changing the outer skin only but not changing its contents; 2) transformed into small groups that global and sporadic; 3) turns into unactive groups that waiting for a signal to start their mission again; 4) change becomes stronger groups; 5) or just become weaker. These possibilities will also continue to be filled with the basic thoughts held by Aman Abdurrahman and ISIS ideological propaganda (although the percentage of the effects will vary from individual to individual). The point of the influence of Aman Abdurrahman's thinking was between the mind or basic knowledge that Aman Abdurrahman possessed and the influence of ISIS propaganda through his media (ISIS media). Those point becomes a strong foundation that can accommodate or break down three other benchmarks (communication, network and media) in accordance with how the pro-ISIS network projection in Indonesia will be directed.

\section{ACKNOWLEDGEMENT}

This research based on grant scheme of PITTA (publikasi international terindeks untuk tugas akhir) or also known as indexed international publications for final projects toward universitas indonesia students. Thank you to Dr. muhammad luthfi and Muhammad Imdadun Rahmat as my advisor. 


\section{REFERENCES}

[1]. Abdurrahman, A. (n.d.). Seri Materi Tauhid. (n.p.).

[2]. Abdurrahan, A. (2010). Kalau Bukan Tauhid, Apa lagi? Membedah NKRI dengan Millah Ibrahim. Depok, Jawa Barat: Ats-Tsughuur Media.

[3]. Al-Indunisy, A. J. (n.d.). Adab dan Akhlaq Khawarij Modern - Studi Kritis Kesesatan Manhaj Aman Abdurrahman - Hadahullah. (n.p.): Aliansi Muslim Anti Kemunkaran (AMAK).

[4]. Amindoni, A. (2018, July 17). Bagaimana kekuatan JAD saat ini setelah pemburuan masif oleh polisi. BBC News Indonesia. Retrieved from https://www.bbc.com/indonesia/indonesia-44777539.

[5]. Dhanaraj, J. (2018). "Evolution of the Islamic State After its Territorial Defeat". Counter Terrorist Trends and Analyses, 10(5), 1-7.

[6]. Dreher, J. (2016). "The Social Construction of Power: Reflections Beyond Berger/Luckmann and Bourdieu”. Cultural Sociology, 10(1), 53-68.

[7]. Gunaratna, R. (2018). "Global Threat Forecast". Counter Terrorist Trends and Analyses, 10(1), 1-6.

[8]. Habulan, A., Taufiqurrohman, M., Haziq, M. (2018). "Southeast Asia - Philippines, Indonesia, Malaysia, Myanmar, Thailand, Singapore, Online Extremism”. Counter Terrorist Trends and Analyses, 10(1), 7-30.

[9]. Huzaifah, S. \& Mahzam, R. (2018). "Islamic State After the Fall of Mosul \& Raqqa: Impact on Organization and Propaganda". Counter Terrorist Trends and Analyses, 10(1), 57-61.

[10]. Indonesia's Lamongan Network: How East Java, Poso and Syria are Linked. (2015, April 15), Institute for Policy Analysis of Conflict (IPAC), p. 1-22.

[11]. Kejaksaan Negeri Jakarta Selatan. (2018, Mei 18). "Tuntutan an. Terdakwa: Oman Rochman alias Aman Abdurrahman alias Abu Sulaiman bin Ade Sudarma". 1-242.

[12]. Moir, N. L. (2017). "ISIL Radicalization, Recruitment, and Social Media Operations in Indonesia, Malaysia, and the Philippines". Journal of the Center for Complex Operations, Volume 07, Issue 01, 90-107

[13]. Rietzer, G. (2010). Sociological Theory. New York, NY: McGraw-Hill.

[14]. (Emil, personal communication, May 24, 2018).

[15]. (Anonymous, personal communication, August 31, 2018).

[16]. (K. Widodo, personal communication, July 26, 2018). 